\title{
Effects of fat supplementation to diets high in nonforage fiber on production responses of midlactation dairy cows
}

\author{
C. M. Ylioja, ${ }^{*}$ C. Abney-Schulte, $†$ R. Stock, $\dagger$ and B. J. Bradford ${ }^{* 1}$ \\ *Department of Animal Sciences and Industry, Kansas State University, Manhattan 66506 \\ †Cargill Inc., Blair, NE 68008
}

\begin{abstract}
The effects of dietary nonforage fiber sources on production responses of lactating dairy cattle have been well described, but interactions with other components of the diet have been less thoroughly explored. We investigated the effects of adding 2 commonly fed fat sources to a ration featuring high levels of nonforage fiber supplied by a corn milling by-product. Midlactation Holstein cows were blocked by parity, stratified by days in milk, and randomly assigned to 1 of 6 pens (12 cows/pen). Pens were randomly assigned to treatment sequences in a $3 \times 3$ Latin square design, where the treatments consisted of prilled saturated fat (SAT; Energy Booster 100, Milk Specialties Co., Dundee, IL), calcium salts of long-chain fatty acids (UNS; Megalac, Church and Dwight Co. Inc., Princeton, NJ), or no added dietary fat (control), with fat sources included to provide $1.2 \%$ added fat (dry matter basis). Treatment periods were $21 \mathrm{~d}$; milk and feed samples were collected and milk yield and feed intake were recorded for the last $4 \mathrm{~d}$ of each period. Results were analyzed with mixed models with pen as the experimental unit, and orthogonal contrasts were employed to evaluate the overall effect of added fat and the effect of fat source. Dry matter intake and milk yield tended to increase with added fat. Protein content decreased with fat supplementation, to a greater degree for UNS than for SAT, but protein yield was not affected. Fat content, fat yield, and energy-corrected milk yield were not affected by treatment. Conversion of feed to milk tended to increase for UNS compared with SAT. Fat supplementation to diets high in nonforage fiber had effects that were similar to those reported for more traditional lactation diets, except for the dry matter intake response.
\end{abstract}

Key words: nonforage fiber, dietary fat

Received October 14, 2017.

Accepted February 19, 2018.

${ }^{1}$ Corresponding author: bbradfor@ksu.edu

\section{INTRODUCTION}

Increased availability of by-product feeds in recent years provides additional options to dairy producers for nutrient supply to dairy cows, allowing for increased flexibility in times of fluctuating feed prices. Many of these by-products are high in fiber and low in starch and can be used in partial replacement of both forage and concentrate in the ration to supply readily digestible energy (Bradford and Mullins, 2012). These by-product feeds often display quite different physical and chemical characteristics from the forage or concentrate feedstuffs being replaced and, as such, can behave differently in the ruminant digestive system. By-product feeds generally feature greater specific gravity and smaller particle size than forages, likely leading to increased passage rate from the rumen (Bhatti and Firkins, 1995) and increased NDF digestion in the hindgut versus the rumen (Firkins, 1997). Additionally, nonforage fiber sources can interact with other feed ingredients, as Holt et al. (2010) observed when adding beet pulp and soyhulls to a ration with brown midrib corn silage compared with conventional corn silage.

Supplemental fat is often added to the ration of dairy cows to increase energy density of the diet and to positively affect milk production and component yield; however, responses to dietary fat are heterogeneous, apparently depending on both type of fat supplemented and the characteristics of the overall diet (Rabiee et al., 2012). Two forms of dietary fat commonly fed to ruminants are calcium salts of fatty acids, which are largely unsaturated in commercial supplements, and prilled SFA. Replacement of forages with high levels of nonforage fiber may result in decreased rumen $\mathrm{pH}$ (Mullins et al., 2010), which may promote dissociation of calcium salts and biohydrogenation of the component fatty acids (Wu et al., 1991). Milk production outcomes have varied in response to saturated fat supplementation depending on accompanying dietary levels of forage NDF (Weiss and Pinos-Rodríguez, 2009; Piantoni et al., 2015). As fibrous by-product feeds displace some conventional fiber sources, production responses to fat 
supplementation need to be further explored in this context. Therefore, the objective of our study was to evaluate effects of saturated or unsaturated fat sources on milk production responses of lactating Holstein cows fed high levels of nonforage fiber.

\section{MATERIALS AND METHODS}

\section{Animal Care}

The study was conducted from January to March of 2015 at the Kansas State University Dairy Teaching and Research Center; all procedures were approved by the Kansas State University Institutional Animal Care and Use Committee.

Seventy-two Holstein cows between 94 and 220 DIM $(166 \pm 25$ DIM, parity $1.7 \pm 0.9$, BW $698 \pm 65$, mean $\pm \mathrm{SD})$ were stratified by parity and DIM, then randomly assigned to pens $(n=6)$ within strata. Each pen contained 6 primiparous and 6 multiparous cows, and mean DIM and milk yield were similar across pens.
Each pen was equipped with fans and sprinklers, 12 stalls bedded with sand, and at least $80 \mathrm{~cm}$ of feed bunk space per cow. Cows were milked twice daily, at 0900 and $2100 \mathrm{~h}$, and had free access to water.

Diet formulations are outlined in Table 1. Dietary fiber was supplied through alfalfa hay, corn silage, and a corn milling product (CMP; OneTrak, Cargill Inc., Blair, NE), which is composed largely of nonforage fiber from wet corn milling processes (Sweet Bran, Cargill Inc.). Previous research has shown that wet corn gluten feed can comprise 35 to $46 \%$ of diet DM without impairing productivity of lactating cows (Boddugari et al., 2001; Mullins et al., 2010; Rezac et al., 2012; Sullivan et al., 2012); CMP also includes supplemental protein, vitamins, and minerals to meet lactating cow requirements and is intended to be fed at $44 \%$ of the diet (DM basis). Feed was mixed daily as a TMR and fed once per day at $0800 \mathrm{~h}$. Dry matter of corn silage was tested weekly and the ration was adjusted accordingly; total feed amount was adjusted as needed to allow for at least $10 \%$ refusals.

Table 1. Ingredient and nutrient composition of diets ${ }^{1}$

\begin{tabular}{|c|c|c|c|}
\hline Item & $\mathrm{CON}$ & UNS & SAT \\
\hline \multicolumn{4}{|l|}{ Ingredient ( $\%$ of DM) } \\
\hline $\mathrm{CMP}^{2}$ & 44.0 & 44.1 & 44.1 \\
\hline Corn silage & 35.5 & 35.6 & 35.7 \\
\hline Alfalfa hay & 8.0 & 8.1 & 8.1 \\
\hline \multicolumn{4}{|l|}{ Grain mix } \\
\hline Corn grain & 10.9 & 10.9 & 10.7 \\
\hline Soybean hulls & 1.5 & - & 0.2 \\
\hline Calcium salts of palm fatty acids ${ }^{3}$ & - & 1.4 & - \\
\hline Prilled hydrogenated fatty acids ${ }^{4}$ & - & - & 1.2 \\
\hline Monensin supplement ${ }^{5}$ & 0.006 & 0.006 & 0.006 \\
\hline \multicolumn{4}{|c|}{ Nutrient composition ${ }^{6}$ (\% of DM, unless noted) } \\
\hline $\mathrm{DM}(\%$, as fed $)$ & 55.8 & 55.7 & 55.5 \\
\hline $\mathrm{CP}$ & 18.0 & 17.9 & 18.0 \\
\hline NDF & 32.9 & 32.0 & 32.4 \\
\hline Starch & 20.1 & 20.8 & 20.3 \\
\hline Crude fat & 3.06 & 4.43 & 3.99 \\
\hline $\mathrm{NE}_{\mathrm{L}}^{7}(\mathrm{Mcal} / \mathrm{kg})$ & 1.60 & 1.63 & 1.63 \\
\hline \multicolumn{4}{|l|}{ Particle size distribution ${ }^{8}(\%$, as fed) } \\
\hline$>19.0 \mathrm{~mm}$ & $2.6 \pm 1.2$ & $3.1 \pm 1.3$ & $2.8 \pm 0.9$ \\
\hline 8.0 to $19.0 \mathrm{~mm}$ & $40.0 \pm 3.3$ & $40.0 \pm 2.6$ & $38.8 \pm 2.6$ \\
\hline 1.18 to $8.0 \mathrm{~mm}$ & $49.9 \pm 2.1$ & $50.0 \pm 2.4$ & $50.7 \pm 2.5$ \\
\hline$<1.18 \mathrm{~mm}$ & $7.5 \pm 1.5$ & $7.0 \pm 1.1$ & $7.8 \pm 1.1$ \\
\hline
\end{tabular}

${ }^{1}$ Treatment diets contained either no added fat $(\mathrm{CON})$, calcium salts of long-chain unsaturated fatty acids (UNS; Megalac, Church and Dwight Co. Inc., Princeton, NJ), or prilled saturated fatty acids (SAT; Energy Booster 100, Milk Specialties Co., Dundee, IL), with fat sources added to provide $1.2 \%$ of added fat.

${ }^{2}$ Corn milling product [OneTrak (Cargill Corn Milling, Blair, NE)], consisting of Sweet Bran (Cargill), protein, vitamins, and minerals.

${ }^{3}$ Megalac (Church and Dwight Co. Inc.).

${ }^{4}$ Energy Booster 100 (Milk Specialties Co.).

${ }^{5}$ Rumensin 90 (Elanco Animal Health, Greenfield, IN).

${ }^{6}$ Calculated using analyzed nutrient analyses from 3 sampling periods.

${ }^{7}$ Net energy values are predicted by Dairy NRC 2001 software using observed values for initial BCS and BW (698 $\mathrm{kg}=$ initial average BW of all cows), milk yield, milk components, and DIM. Default fat digestibility value of 0.86 was used for both supplements (NRC, 2001).

${ }^{8}$ Means \pm SD from 3 sampling periods, 4 sampling days per period $(\mathrm{n}=12)$. 


\section{Treatments and Experimental Design}

Pens were randomly assigned to treatment sequence in a replicated $3 \times 3$ Latin square design balanced for carryover effects. Treatments consisted of no added dietary fat $(\mathbf{C O N})$, calcium salts of long-chain UFA (UNS; Megalac, Church and Dwight Co. Inc., Princeton, NJ), or prilled SFA (SAT; Energy Booster 100, Milk Specialties Co., Dundee, IL), with fat sources replacing soybean hulls to provide $1.2 \%$ added fat (\% of diet DM). Slightly different dietary inclusion rates reflected differences in fatty acid content of the commercial supplements $83 \%$ for UNS [Weiss and Wyatt, 2004] compared with $99 \%$ for SAT [Milk Specialties Co., Dundee, IL]). Fatty acid profiles of these treatments have been previously reported (Elliott et al., 1996; Weiss et al., 2011). Each treatment period was $21 \mathrm{~d}$, allowing for $17 \mathrm{~d}$ of dietary adaptation before samples and data were collected.

\section{Data and Sample Collection}

All milk weights were recorded and milk samples were collected during each milking for the final $4 \mathrm{~d}$ of each period. Milk was analyzed for fat, true protein, lactose (B-2000 Infrared Analyzer; Bentley Instruments Inc., Chaska, MN), MUN (MUN spectrophotometer; Bentley Instruments Inc.), and somatic cells (SCC 500, Bentley Instruments Inc.) at Heart of America DHIA (Manhattan, KS). Somatic cell count was converted to somatic cell linear score $\left[\mathrm{SCLS}=\log _{2}(\mathrm{SCC} / 100)+3\right.$; Shook, 1993] for analysis. Energy-corrected milk yield was calculated as ECM $=(0.327 \times$ milk yield $)+(12.95$ $\times$ fat yield $)+(7.65 \times$ protein yield $)$, and $3.5 \% \mathrm{FCM}$ milk yield was calculated as FCM $=(0.432 \times$ milk yield $)+(16.216 \times$ fat yield $)$.

Feed offered and refused was recorded during d 17 through 20 of each period, and TMR particle size was assessed with the Penn State particle separator (Kononoff et al., 2003). Samples of TMR and dietary ingredients (corn silage, alfalfa hay, CMP, and grain mix) were also collected during d 17 through 20 of each period and composited for analysis. All feed samples were sent to Dairy One Forage Laboratory (Ithaca, NY) for nutrient analysis (Table 2) using wet chemistry. Dry matter content was determined by drying at $105^{\circ} \mathrm{C}$ (method 2.2.2.5; Undersander et al., 1993), and also at $60^{\circ} \mathrm{C}$ to better avoid loss of volatile nutrients in some feedstuffs (Thiex and Richardson, 2003). Crude protein was determined via combustion in a Leco CN682 Carbon/Nitrogen Determinator (Leco Corp., St. Joseph, MI) to obtain nitrogen content, then multiplying by 6.25 (method 990.03; AOAC International, 2012). Acid detergent fiber was determined by acid detergent diges- tion in an Ankom A200 Digestion Unit (Ankom Technology, Macedon, NY). Neutral detergent fiber was determined by digestion in a neutral detergent solution with the addition of $\alpha$-amylase and sodium sulfite (Van Soest et al., 1991). Crude fat (or ether extract) was obtained via extraction with diethyl ether in a Soxtec HT6 System (Foss North America, Eden Prairie, MN; method 2003.05; AOAC International, 2012); grain mix containing calcium salts of fatty acids was subject to acid hydrolysis before ether extraction (method 954.02; AOAC International, 2012). Nonfiber carbohydrates were calculated by difference $[\mathrm{NFC}=100-(\% \mathrm{NDF}$ $+\% \mathrm{CP}+\%$ ether extract $+\%$ ash)]. Starch was determined by first extracting sugar via water bath incubation at $40^{\circ} \mathrm{C}$ followed by filtration, hydrolyzing starch to dextrose with glucoamylase enzyme, and analyzing dextrose concentration via YSI 2700 Biochemistry Analyzer (YSI Inc. Life Sciences, Yellow Springs, OH).

Two methods of calculating production efficiency were used. Milk, ECM, and FCM yields per unit of DMI were assessed. Additionally, $\mathrm{NE}_{\mathrm{L}}$ density values were predicted with NRC (2001) software using observed values for milk components, milk yield, initial BCS and BW, feed intake, and DIM as well as feed nutrient analyses. The NRC (2001) default value of 0.86 for fat digestibility was used for both supplemental sources. Efficiency of energy use was calculated as $\mathrm{NE}_{\mathrm{L}}$ output in milk (Mcal/d) divided by intake of predicted dietary $\mathrm{NE}_{\mathrm{L}}$ (Mcal/d). Net energy concentration in milk was calculated as $\mathrm{NE}_{\mathrm{L}}(\mathrm{Mcal} / \mathrm{kg})=0.0929 \times$ fat $\%+0.0563 \times$ true protein $\%+0.0395 \times$ lactose $\%$ (NRC, 2001).

Body condition score was assessed at the beginning and end of each period by 3 trained individuals and averaged per time point. One cow on the SAT treatment was removed from the study after period 1 due to mastitis and was replaced for periods 2 and 3 . Two cows ( 1 from CON and 1 from SAT) were removed due to unrelated illness during period 3 , resulting in 2 pens of 11 cows and 4 pens of 12 cows for period 3 data collection.

\section{Data Analysis}

Statistical analysis was performed using SAS (version 9.3, SAS Institute Inc., Cary, NC). Milk production outcomes were analyzed with treatment as a fixed effect and pen, period, cow within pen, and pen $\times$ treatment as random effects. Inclusion of effect of cow in the model allowed for adjustment due to cows that were removed early from the study; denominator degrees of freedom were used to verify that pen was treated as experimental unit. Pen-level feed intake was divided by the number of cows in the pen and analyzed with 


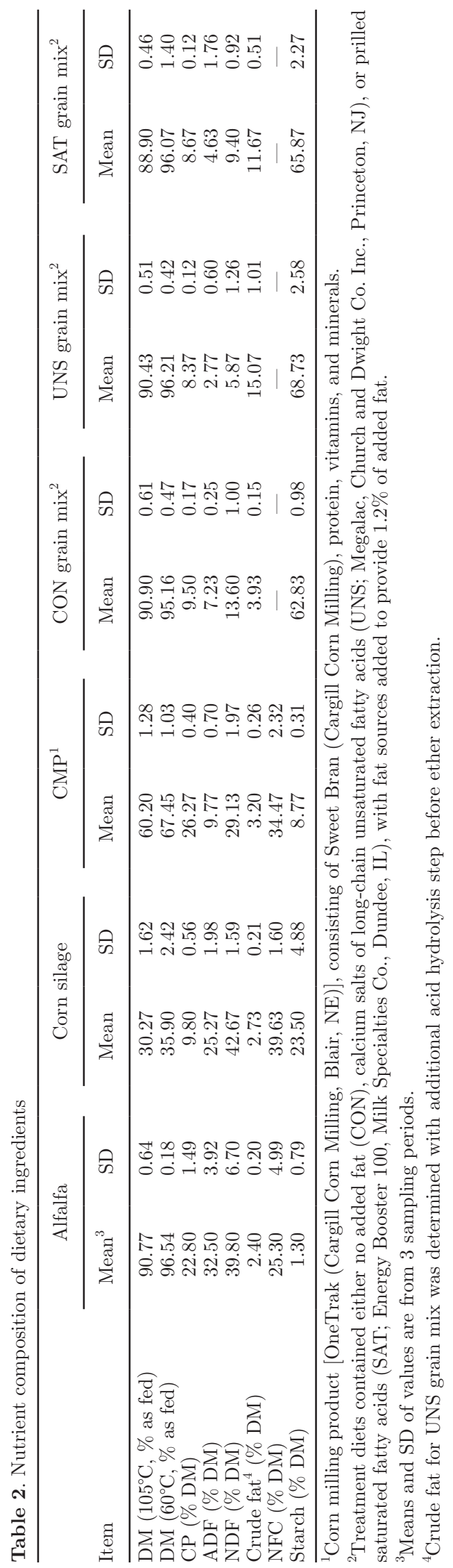

treatment as a fixed effect and pen and period as random effects. Treatment means were evaluated using the orthogonal contrasts (1) effect of fat supplementation (CON vs. UNS and SAT) and (2) effect of fat source (UNS vs. SAT). Significance was declared at $P<0.05$ and tendencies were declared at $0.05 \leq P<0.10$.

\section{RESULTS}

Production responses to fat supplementation are summarized in Table 3. Dry matter intake tended to increase with fat supplementation $(P=0.07)$. Fat supplementation tended to increase milk yield by $2 \%(P=$ 0.06 ) with no difference between fat sources. Milk fat concentration and yield were not affected by treatment. The FCM tended to increase with additional dietary fat $(P=0.09)$, but ECM was unaffected. Milk protein concentration decreased with the addition of fat $(P=$ 0.001) to a greater extent for UNS than for SAT (effect of source $P=0.02$ ). Milk protein yield, however, was unaffected by treatment. Milk urea nitrogen decreased with both sources of fat supplementation $(P=0.04)$. UNS tended to increase the conversion of feed to milk compared with SAT (effect of source $P=0.06$ ), but neither treatment affected efficiency of ECM or FCM production. Fat supplementation decreased net energy conversion from feed to milk compared with CON (0.64 and 0.63 vs. $0.65 \pm 0.02$ for UNS, SAT, and CON, respectively; $P=0.04$ ). No treatment differences were detected for changes in BCS during the study.

\section{DISCUSSION}

Effects of fat supplementation on lactation have been well documented, but evidence of differential effects of different fat sources, and responses that may depend on animal or basal diet characteristics (Rabiee et al., 2012), point to lingering questions of economic significance for dairy producers.

Increased dietary fat often decreases DMI, and mechanisms for this may involve altered fiber fermentation, motility or passage rate from the rumen, diet palatability, oxidation of fuels, or gut peptide secretion (Allen, 2000; Harvatine and Allen, 2005; Relling and Reynolds, 2007). However, we observed a tendency for an increase in feed intake in response to fat supplementation. A handful of others have reported similar results; Mosley et al. (2007) added increasing concentrations of palm oil to a diet of mainly alfalfa and corn grain and reported increased DMI only by the group supplemented at $1.8 \%$ of DM, whereas DMI decreased with greater inclusion levels. Stoffel et al. (2015) reported no effects on DMI, however, with similarly low levels of palm oil supplementation. Differing results could be attributed 
YLIOJA ET AL.

Table 3. Effect of supplemental fat on milk production parameters

\begin{tabular}{|c|c|c|c|c|c|c|}
\hline \multirow[b]{2}{*}{ Item } & \multicolumn{3}{|c|}{$\operatorname{Diet}^{1}$} & \multirow[b]{2}{*}{ SEM } & \multicolumn{2}{|c|}{$P$-value } \\
\hline & $\mathrm{CON}$ & UNS & SAT & & Added fat & Source \\
\hline Milk yield $(\mathrm{kg} / \mathrm{d})$ & 33.5 & 34.3 & 34.2 & 1.3 & 0.06 & 0.64 \\
\hline Fat $(\%)$ & 3.95 & 3.92 & 3.92 & 0.10 & 0.57 & 0.92 \\
\hline Fat yield $(\mathrm{kg} / \mathrm{d})$ & 1.31 & 1.34 & 1.33 & 0.057 & 0.19 & 0.86 \\
\hline Protein $(\%)$ & 3.43 & 3.31 & 3.37 & 0.052 & 0.001 & 0.02 \\
\hline Protein yield (kg/d) & 1.14 & 1.13 & 1.14 & 0.038 & 0.59 & 0.24 \\
\hline Lactose (\%) & 4.81 & 4.80 & 4.80 & 0.048 & 0.79 & 0.92 \\
\hline Lactose yield (kg/d) & 1.62 & 1.65 & 1.65 & 0.073 & 0.12 & 0.87 \\
\hline MUN (mg/dL) & 13.98 & 13.55 & 13.48 & 0.57 & 0.04 & 0.75 \\
\hline SCLS $^{2}$ & 1.99 & 1.95 & 2.00 & 0.19 & 0.92 & 0.69 \\
\hline $\operatorname{ECM}(\mathrm{kg} / \mathrm{d})$ & 36.5 & 37.1 & 37.1 & 1.4 & 0.18 & 0.99 \\
\hline $3.5 \%$ FCM $(\mathrm{kg} / \mathrm{d})$ & 35.7 & 36.5 & 36.4 & 1.4 & 0.09 & 0.75 \\
\hline DMI $(\mathrm{kg} / \mathrm{d})$ & 24.2 & 24.5 & 24.7 & 0.34 & 0.07 & 0.48 \\
\hline $\mathrm{NE}_{\mathrm{L}}$ intake 3 (Mcal/d) & 38.75 & 40.00 & 40.22 & 0.55 & $<0.01$ & 0.53 \\
\hline Milk/DMI & 1.39 & 1.41 & 1.38 & 0.049 & 0.70 & 0.06 \\
\hline ECM/DMI & 1.53 & 1.54 & 1.51 & 0.052 & 0.68 & 0.18 \\
\hline FCM/DMI & 1.49 & 1.51 & 1.48 & 0.051 & 0.87 & 0.13 \\
\hline Milk $\mathrm{NE}_{\mathrm{L}} / \mathrm{NE}_{\mathrm{L}}$ intake $^{4}$ & 0.652 & 0.640 & 0.632 & 0.022 & 0.04 & 0.25 \\
\hline Initial BCS & 3.45 & 3.44 & 3.47 & 0.12 & 0.99 & 0.46 \\
\hline Final BCS & 3.57 & 3.56 & 3.58 & 0.074 & 0.98 & 0.56 \\
\hline BCS change $/ 21 \mathrm{~d}$ & 0.12 & 0.12 & 0.12 & 0.070 & 0.95 & 0.94 \\
\hline
\end{tabular}

${ }^{1}$ Treatment diets contained either no added fat $(\mathrm{CON})$, calcium salts of long-chain unsaturated fatty acids (UNS; Megalac, Church and Dwight Co. Inc., Princeton, NJ), or prilled saturated fatty acids (SAT; Energy Booster 100, Milk Specialties Co., Dundee, IL), with fat sources added to provide $1.2 \%$ of added fat.

${ }^{2}$ Somatic cell linear score $=\log _{2}(\mathrm{SCC} / 100)+3$ (Shook, 1993).

${ }^{3} \mathrm{NE}_{\mathrm{L}}$ intake was estimated by NRC (2001) software using observed values for initial BCS and BW $(698 \mathrm{~kg}=$ initial average BW of all cows), DMI, milk yield, milk components, and DIM.

${ }^{4}$ Milk $\mathrm{NE}_{\mathrm{L}}=0.0929 \times$ fat $\%+0.0563 \times$ true protein $\%+0.0395 \times$ lactose $\%(\mathrm{NRC}, 2001)$.

to variation in dietary fiber content between studies or interactions with other feed ingredients used. Weiss and Pinos-Rodríguez (2009) added a prilled saturated fat to diets differing in NDF source, with fiber supplied by either corn silage and alfalfa or by soybean hulls and wheat middlings in partial replacement of the forages. Cows fed the low-forage diet in their study had greater DMI with added fat only from wk 4 to 6 of lactation, whereas supplemental fat increased DMI over wk 4 to 15 of lactation within cows fed high-forage diets. This indicates possible associative effects (ruminal or otherwise) between fat supplementation and NDF source. Such an interaction could also be a contributing factor to the DMI response observed in the current study, where nonforage NDF made up $13.9 \%$ of the dietary DM.

Factors determining feed intake generally fall under physical (gut fill) or metabolic constraints (Allen, 2000). Particle size and digestibility of fiber affect passage rate from the rumen; larger and more lignified particles require increased rumination to achieve adequate breakdown in size to allow passage from the rumen. Fibrolytic activity can be reduced with addition of fat, largely through physical coating of feedstuffs and reduced accessibility to microbial breakdown (Jenkins, 1993), as well as through toxic effects of UFA on bacte- rial growth and cellular integrity (Maia et al., 2007). Prilled saturated fats and calcium salts of fatty acids are considered to be fairly inert in the rumen (Grummer, 1988; Palmquist, 1991), although VFA production can be negatively affected by saturated fats (Harvatine and Allen, 2006) and some biohydrogenation and disappearance in the rumen does occur for fatty acids fed as calcium salts (Wu et al., 1991). The effect of dietary fat may vary with fiber source in the ration. Nonforage sources of fiber inherently feature reduced particle size and greater surface area, and fibrolytic activity may be less inhibited by physical coating of feed particles compared with more structural forage sources of fiber, particularly at lower levels of fat supplementation. Lewis et al. (1999) reported increased VFA concentration from short versus long hay in the presence of tallow, but not in its absence, suggesting tallow may affect fermentation or VFA clearance differently when fiber particles were small. Ramirez Ramirez et al. (2016) observed increased trans-10, cis-12 CLA in milk when corn oil was fed with short particle grass hay compared with longer hay particles, indicating that smaller particle size may also limit the extent of biohydrogenation of associated lipids. Although the extent of dietary fatty acid biohydrogenation is unknown in the current study, it is possible that interactions between NDF source, 
particle size, dietary fat, and even other dietary components contributed to the feed intake response observed in our study.

Milk production responses to fat supplementation have been extensively described by others (Schroeder et al., 2004; Rabiee et al., 2012) and can be attributed to effects on rumen activity, postruminal digestion, and nutrient use and partitioning, including by the mammary gland itself. The observed effect on milk protein in our study is consistent with the literature on fat supplementation reviewed by multiple groups (Wu and Huber, 1994; Onetti and Grummer, 2004; Schroeder et al., 2004; Rabiee et al., 2012). Although protein concentration decreased, the slight increase in milk yield with fat supplementation appeared to compensate, such that total milk protein production showed no treatment effects. We did not explore the mechanism for the protein response to dietary fat, but work by others has suggested possibilities. Cant et al. (1993) measured arteriovenous blood flow across the mammary gland with fat supplementation and found a decrease in blood flow per kilogram of milk. Increased dietary lipid availability for mammary uptake may spare acetate from fatty acid synthesis toward fueling metabolism within the gland instead (DePeters and Cant, 1992; Schroeder et al., 2004). If this increased efficiency of nutrient utilization is not accompanied by an increase in AA concentration in blood supplying the mammary gland ( $\mathrm{Wu}$ and Huber, 1994), it may allow for increased milk volume and milk fat production with no change in milk protein production. In our study, fat supplementation tended to increase milk yield as well as FCM yield, although fat yield was not significantly different. The observed decrease in milk protein concentration in response to unsaturated dietary fat relative to saturated fat sources is also consistent with the literature; a meta-analysis by Rabiee et al. (2012) reported that prilled fats had relatively small effects on milk protein, whereas calcium salts had more negative effects. Differences in saturation of fatty acids could affect microbial protein production or insulin signaling (Harvatine and Allen, 2005), ultimately altering AA transport into the mammary gland.

Altered MUN values observed in our study could arguably be interpreted as of little biological significance, as the magnitude of the treatment effect was small. However, the observed decrease with fat supplementation would be consistent with the possibility of altered nutrient uptake leading to decreased milk protein concentration (Cant et al., 1993), as transfer of plasma urea into milk may have been similarly affected. Alternatively, regression analysis found MUN concentration to be negatively related to milk yield (Broderick and Clayton, 1997). Assuming that protein degradation and ammonia flow from the rumen were relatively unaffected by fat supplementation in the current study, the tendency for increased milk volume observed may have simply diluted the urea nitrogen excreted in milk.

Although increased efficiency of energy utilization by the mammary gland is often one of the reported benefits of fat supplementation (Schroeder et al., 2004), we detected no differences for efficiency measures of ECM or FCM per unit of DMI. We also calculated efficiency of energy utilization as the ratio of net energy in milk per unit of predicted $\mathrm{NE}_{\mathrm{L}}$ intake. In this case, both sources of supplemented fat decreased the efficiency of feed net energy conversion to milk energy compared with CON, which could be attributed to differences in digestibility or nutrient partitioning. In later-lactation cows, supplemental fat has been partitioned to body stores rather than to mammary output (Pantoja et al., 1996; Weiss and Pinos-Rodríguez, 2009). Although we did not detect changes in BCS during the 3-wk periods of the current experiment, we acknowledge the limited precision of estimates of changes in both BCS and BW over such a short window of time and allow that changes in body composition could have contributed to differences in efficiency of feed energy use for milk in the current study. Additionally, meta-analysis of studies reporting digestibility data revealed that digestibility of individual fatty acids may be affected by relative saturation as well as overall fatty acid profile (Boerman et al., 2015). In general, fatty acid intake and duodenal fatty acid flow were negatively related to fatty acid digestibility. Digestibilities of C18:0 as well as UFA (C18:1, C18:2, and C18:3) were negatively correlated with the duodenal flow of C18:0, whereas C16:0 digestibility was not affected by duodenal supply of C:16 (Boerman et al., 2015). In the current study, increased total fatty acid intake $(1,085$ and $986 \mathrm{~g} / \mathrm{d}$ for UNS and SAT, respectively) as well as the C18:0 content in SAT (41\% of total fatty acids; Weiss et al., 2011) may have contributed to negative effects on fatty acid digestibility, depressing the absorbed energy available for mammary use for both dietary treatments. In addition, White et al. (2017) recently reported that the NRC (2001) model likely overpredicts fatty acid digestion by an average of $26 \%$, which may help to explain a decrease in calculated conversion efficiency for our supplemental diets.

\section{CONCLUSIONS}

Fat supplementation to diets high in nonforage fiber yielded decreased milk protein and MUN concentrations and showed tendencies for increased DMI and milk yield. Dietary fat decreased net energy conversion efficiency from feed to milk compared with CON, possi- 
bly due to effects on fatty acid digestibility or nutrient partitioning. Milk production and component responses are likely a function of changes in substrate availability and utilization due to fat supplementation, whereas effects on DMI may be more attributable to interactions of fat with nonforage fiber and the rumen microbial environment. The observed magnitude of response suggests that adding fat to similar diets based on nonforage fiber may be of marginal added benefit, although it is likely that responses differ by stage of lactation.

\section{ACKNOWLEDGMENTS}

Contribution no. 18-091-J from the Kansas Agricultural Experiment Station (Manhattan, KS). The authors gratefully acknowledge the assistance of Mike Scheffel and the employees of KSU Dairy Teaching and Research Center (Manhattan, KS), as well as Cargill Inc. (Blair, NE) for partial financial support of this project.

\section{REFERENCES}

Allen, M. S. 2000. Effects of diet on short-term regulation of feed intake by lactating dairy cattle. J. Dairy Sci. 83:1598-1624. https:// doi.org/10.3168/jds.S0022-0302(00)75030-2.

AOAC International. 2012. Official Methods of Analysis. 19th ed. AOAC International, Gaithersburg, MD.

Bhatti, S. A., and J. L. Firkins. 1995. Kinetics of hydration and functional specific gravity of fibrous feed by-products. J. Anim. Sci. 73:1449-1458. https://doi.org/10.2527/1995.7351449x.

Boddugari, K., R. J. Grant, R. Stock, and M. Lewis. 2001. Maximal replacement of forage and concentrate with a new wet corn milling product for lactating dairy cows. J. Dairy Sci. 84:873-884. https:// doi.org/10.3168/jds.S0022-0302(01)74545-6.

Boerman, J. P., J. L. Firkins, N. R. St-Pierre, and A. L. Lock. 2015 Intestinal digestibility of long-chain fatty acids in lactating dairy cows: A meta-analysis and meta regression. J. Dairy Sci. 98:88898903. https://doi.org/10.3168/jds.2015-9592.

Bradford, B. J., and C. R. Mullins. 2012. Invited review: strategies for promoting productivity and health of dairy cattle by feeding nonforage fiber sources. J. Dairy Sci. 95:4735-4746. https://doi.org/ $10.3168 /$ jds.2012-5393.

Broderick, G. A., and M. K. Clayton. 1997. A statistical evaluation of animal and nutritional factors influencing concentrations of milk urea nitrogen. J. Dairy Sci. 80:2964-2971. https://doi.org/10 .3168/jds.S0022-0302(97)76262-3

Cant, J. P., E. J. DePeters, and R. L. Baldwin. 1993. Mammary amino acid utilization in dairy cows fed fat and its relationship to milk protein depression. J. Dairy Sci. 76:762-774. https://doi.org/10 .3168/jds.S0022-0302(93)77400-7.

DePeters, E. J., and J. P. Cant. 1992. Nutritional factors influencing the nitrogen composition of bovine milk: A review. J. Dairy Sci 75:2043-2070. https://doi.org/10.3168/jds.S0022-0302(92)77964 $-8$.

Elliott, J. P., J. K. Drackley, and D. J. Weigel. 1996. Digestibility and effects of hydrogenated palm fatty acid distillate in lactating dairy cows. J. Dairy Sci. 79:1031-1039. https://doi.org/10.3168/ jds.S0022-0302(96)76456-1.

Firkins, J. L. 1997. Effects of feeding nonforage fiber sources on site of fiber digestion. J. Dairy Sci. 80:1426-1437. https://doi.org/10 .3168/jds.S0022-0302(97)76072-7.

Grummer, R. R. 1988. Influence of prilled fat and calcium salt of palm oil fatty acids on ruminal fermentation and nutrient digest- ibility. J. Dairy Sci. 71:117-123. https://doi.org/10.3168/jds.S0022 -0302(88)79532-6.

Harvatine, K. J., and M. S. Allen. 2005. The effect of production level on feed intake, milk yield, and endocrine responses to two fatty acid supplements in lactating cows. J. Dairy Sci. 88:4018-4027. https://doi.org/10.3168/jds.S0022-0302(05)73088-5.

Harvatine, K. J., and M. S. Allen. 2006. Effects of fatty acid supplements on ruminal and total tract nutrient digestion in lactating dairy cows. J. Dairy Sci. 89:1092-1103. https://doi.org/10.3168/ jds.S0022-0302(06)72177-4.

Holt, M. S., C. M. Williams, C. M. Dschaak, J.-S. Eun, and A. J. Young. 2010. Effects of corn silage hybrids and dietary nonforage fiber sources on feed intake, digestibility, ruminal fermentation, and productive performance of lactating Holstein dairy cows. J. Dairy Sci. 93:5397-5407. https://doi.org/10.3168/jds.2010-3411.

Jenkins, T. C. 1993. Lipid metabolism in the rumen. J. Dairy Sci. 76:3851-3863. https://doi.org/10.3168/jds.S0022-0302(93)77727 $-9$.

Kononoff, P. J., A. J. Heinrichs, and D. R. Buckmaster. 2003. Modification of the Penn State forage and total mixed ration particle separator and the effects of moisture content on its measurements. J. Dairy Sci. 86:1858-1863. https://doi.org/10.3168/jds.S0022 -0302(03)73773-4.

Lewis, W. D., J. A. Bertrand, and T. C. Jenkins. 1999. Interaction of tallow and hay particle size on ruminal parameters. J. Dairy Sci. 82:1532-1537. https://doi.org/10.3168/jds.S0022-0302(99)75380 -4 .

Maia, M. R. G., L. C. Chaudhary, L. Figueres, and R. J. Wallace. 2007. Metabolism of polyunsaturated fatty acids and their toxicity to the microflora of the rumen. Antonie van Leeuwenhoek 91:303-314. https://doi.org/10.1007/s10482-006-9118-2.

Mosley, S. A., E. E. Mosley, B. Hatch, J. I. Szasz, A. Corato, N. Zacharias, D. Howes, and M. A. McGuire. 2007. Effect of varying levels of fatty acids from palm oil on feed intake and milk production in Holstein cows. J. Dairy Sci. 90:987-993. https://doi.org/10.3168/ jds.S0022-0302(07)71583-7.

Mullins, C. R., K. N. Grigsby, D. E. Anderson, E. C. Titgemeyer, and B. J. Bradford. 2010. Effects of feeding increasing levels of wet corn gluten feed on production and ruminal fermentation in lactating dairy cows. J. Dairy Sci. 93:5329-5337. https://doi.org/ 10.3168/jds.2010-3310.

National Research Council. 2001. Nutrient Requirements of Dairy Cattle. 7th rev. ed. Natl. Acad. Sci., Washington, DC.

Onetti, S. G., and R. R. Grummer. 2004. Response of lactating cows to three supplemental fat sources as affected by forage in the diet and stage of lactation: A meta-analysis of literature. Anim. Feed Sci. Technol. 115:65-82. https://doi.org/10.1016/j.anifeedsci.2004 .02.009.

Palmquist, D. L. 1991. Influence of source and amount of dietary fat on digestibility in lactating cows. J. Dairy Sci. 74:1354-1360. https://doi.org/10.3168/jds.S0022-0302(91)78290-8.

Pantoja, J., J. L. Firkins, and M. L. Eastridge. 1996. Fatty acid digestibility and lactation performance by dairy cows fed fats varying in degree of saturation. J. Dairy Sci. 79:429-437. https://doi.org/10 $.3168 /$ jds.S0022-0302(96)76382-8.

Piantoni, P., A. L. Lock, and M. S. Allen. 2015. Saturated fat supplementation interacts with dietary forage neutral detergent fiber content during the immediate postpartum and carryover periods in Holstein cows: Production responses and digestibility of nutrients. J. Dairy Sci. 98:3309-3322. https://doi.org/10.3168/jds.2014 -8798 .

Rabiee, A. R., K. Breinhild, W. Scott, H. M. Golder, E. Block, and I. J. Lean. 2012. Effect of fat additions to diets of dairy cattle on milk production and components: a meta-analysis and metaregression. J. Dairy Sci. 95:3225-3247. https://doi.org/10.3168/ jds.2011-4895.

Ramirez Ramirez, H. A., K. J. Harvatine, and P. J. Kononoff. 2016 Short communication: Forage particle size and fat intake affect rumen passage, the fatty acid profile of milk, and milk fat production in dairy cows consuming dried distillers grains with solubles. J. Dairy Sci. 99:392-398. https://doi.org/10.3168/jds.2015-10006. 
Relling, A. E., and C. K. Reynolds. 2007. Feeding rumen-inert fats differing in their degree of saturation decreases intake and increases plasma concentrations of gut peptides in lactating dairy cows. J. Dairy Sci. 90:1506-1515. https://doi.org/10.3168/jds.S0022 -0302(07)71636-3.

Rezac, D. J., K. N. Grigsby, N. M. Bello, and B. J. Bradford. 2012. Effects of varying rates of tallgrass prairie hay and wet corn gluten feed on productivity of lactating dairy cows. J. Dairy Sci. 95:842-849.

Schroeder, G. F., G. A. Gagliostro, F. Bargo, J. E. Delahoy, and L. D. Muller. 2004. Effects of fat supplementation on milk production and composition by dairy cows on pasture: A review. Livest. Prod. Sci. 86:1-18. https://doi.org/10.1016/S0301-6226(03)00118-0.

Shook, G. E. 1993. Genetic Improvement of mastitis through selection on somatic cell count. Vet. Clin. North Am. Food Anim. Pract. 9:563-581.

Stoffel, C. M., P. M. Crump, and L. E. Armentano. 2015. Effect of dietary fatty acid supplements, varying in fatty acid composition, on milk fat secretion in dairy cattle fed diets supplemented to less than $3 \%$ total fatty acids. J. Dairy Sci. 98:431-442. https://doi .org/10.3168/jds.2014-8328.

Sullivan, M. L., K. N. Grigsby, and B. J. Bradford. 2012. Effects of wet corn gluten feed on ruminal $\mathrm{pH}$ and productivity of lactating dairy cattle fed diets with sufficient physically effective fiber. J. Dairy Sci. 95:5213-5220. https://doi.org/10.3168/jds.2012-5320.

Thiex, N., and C. R. Richardson. 2003. Challenges in measuring moisture content of feeds. J. Anim. Sci. 81:3255-3266.

Undersander, D., D. R. Mertens, and N. Thiex. 1993. Forage Analyses Procedures. National Forage Testing Association, Omaha, NE. Accessed August 14, 2017. http://foragetesting.org/files/ LaboratoryProcedures.pdf.
Van Soest, P. J., J. B. Robertson, and B. A. Lewis. 1991. Methods for dietary fiber, neutral detergent fiber, and nonstarch polysaccharides in relation to animal nutrition. J. Dairy Sci. 74:3583-3597. https://doi.org/10.3168/jds.S0022-0302(91)78551-2.

Weiss, W. P., and J. M. Pinos-Rodríguez. 2009. Production responses of dairy cows when fed supplemental fat in low- and high-forage diets. J. Dairy Sci. 92:6144-6155. https://doi.org/10.3168/jds.2009 $-2558$.

Weiss, W. P.. J. M. Pinos-Rodríguez, and D. J. Wyatt. 2011. The value of different fat supplements as sources of digestible energy for lactating dairy cows. J. Dairy Sci. 94:931-939. https://doi.org/ $10.3168 /$ jds.2010-3745.

Weiss, W. P., and D. J. Wyatt. 2004. Digestible energy values of diets with different fat supplements when fed to lactating dairy cows. J. Dairy Sci. 87:1446-1454. https://doi.org/10.3168/jds.S0022 -0302(04)73295-6.

White, R. R., Y. Roman-Garcia, J. L. Firkins, M. J. VandeHaar, L. E. Armentano, W. P. Weiss, T. McGill, R. Garnett, and M. D. Hanigan. 2017. Evaluation of the National Research Council (2001) dairy model and derivation of new prediction equations. 1. Digestibility of fiber, fat, protein, and nonfiber carbohydrate. J. Dairy Sci. 100:3591-3610. https://doi.org/10.3168/jds.2015-10800.

Wu, Z., and J. T. Huber. 1994. Relationship between dietary fat supplementation and milk protein concentration in lactating cows: A review. Livest. Prod. Sci. 39:141-155.

Wu, Z., O. A. Ohajuruka, and D. L. Palmquist. 1991. Ruminal synthesis, biohydrogenation, and digestibility of fatty acids by dairy cows. J. Dairy Sci. 74:3025-3034. https://doi.org/10.3168/jds .S0022-0302(91)78488-9. 